\title{
Cholinergic Modulation of Neostriatal Output: A Functional Antagonism between Different Types of Muscarinic Receptors
}

\author{
Elvira Galarraga, ${ }^{1}$ Salvador Hernández-López, ${ }^{1}$ Arturo Reyes, ${ }^{3}$ Isabel Miranda, ${ }^{2}$ Federico Bermudez-Rattoni, ${ }^{2}$ \\ Carmen Vilchis, ${ }^{1}$ and José Bargas ${ }^{1}$
}

Departments of ${ }^{1}$ Biophysics and ${ }^{2}$ Neurosciences, Instituto de Fisiología Celular, Universidad Nacional Autónoma de

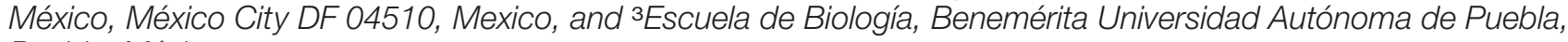
Puebla, México

It is demonstrated that acetylcholine released from cholinergic interneurons modulates the excitability of neostriatal projection neurons. Physostigmine and neostigmine increase input resistance $\left(R_{N}\right)$ and enhance evoked discharge of spiny projection neurons in a manner similar to muscarine. Muscarinic $R_{N}$ increase occurs in the whole subthreshold voltage range $(-100$ to $-45 \mathrm{mV}$ ), remains in the presence of TTX and $\mathrm{Cd}^{2+}$, and can be blocked by the relatively selective $M_{1,4}$ muscarinic receptor antagonist pirenzepine but not by $M_{2}$ or $M_{3}$ selective antagonists. $\mathrm{Cs}^{+}$occludes muscarinic effects at potentials more negative than $-80 \mathrm{mV}$. $\mathrm{A} \mathrm{Na}^{+}$reduction in the bath occludes muscarinic effects at potentials more positive than $-70 \mathrm{mV}$. Thus, muscarinic effects involve different ionic conductances: inward rectifying and cationic. The relatively selective $M_{2}$ receptor antagonist AF-DX 116 does not block muscarinic effects

Neostriatal cholinergic innervation participates in motor control by the basal ganglia (Wang and McGinty 1997; Wilson, 1998). Muscarinic $\mathrm{M}_{1}$ receptor activation facilitates spiny neurons (Dodt and Misgeld, 1986; Misgeld et al., 1986; Pineda et al., 1995; Harsing and Zigmond, 1998) by inhibiting calcium and potassium currents that participate in firing, afterhyperpolarization, and inward rectification (Misgeld et al., 1986; Bargas and Galarraga, 1995; Howe and Surmeier, 1995; Pineda et al., 1995; Hsu et al., 1996). Moreover, muscarinic receptors of the $M_{2}$ type may work as presynaptic autoreceptors that modify the release of $\mathrm{ACh}$ from spontaneously firing cholinergic interneurons (Consolo et al., 1987; Weiler, 1989; Wilson et al., 1990; Kawaguchi, 1992; Hersch et al., 1994).

Despite these physiological actions, the effects of muscarinic receptor antagonists are not as reproducible as those of 3,4dihydroxy-L-phenylalanine (L-DOPA) at the systemic level. Therefore, they do not constitute the treatment of choice for basal ganglia dysfunctions such as Parkinson's disease (Kopin, 1993; Riederer et al., 1993). Nevertheless, several muscarinic receptors have been cloned $\left(\mathrm{M}_{1}-\mathrm{M}_{5}\right)$, and relatively selective ligands are now accessible (Potter and Purkerson, 1995; Caulfield and Bird-

Received Dec. 11, 1998; revised Jan. 28, 1999; accepted Feb. 16, 1999.

This work was supported in part by Dirección General de Asuntos del Personal Académico-Universidad Nacional Autónoma de México Grants IN201397 and IN201597 and Consejo Nacional de Ciencia y Tecnologâa Grants 400346-5-25812N and 3260PN9608. We thank Dagoberto Tapia for skillful help in anatomical work.

Correspondence should be addressed to Dr. Elvira Galarraga, Instituto de Fisiología Celular, Universidad Nacional Autónoma de México, P.O. Box 70-253, México DF 04510, México.

Copyright (C) 1999 Society for Neuroscience $\quad 0270-6474 / 99 / 193629-10 \$ 05.00 / 0$ on the projection neuron but, surprisingly, has the ability to mimic agonistic actions increasing $R_{N}$ and firing. Both effects are blocked by pirenzepine. HPLC measurements of acetylcholine demonstrate that AF-DX 116 but not pirenzepine greatly increases endogenous acetylcholine release in brain slices. Therefore, the effects of the $\mathrm{M}_{2}$ antagonist on the projection neurons were attributable to autoreceptor block on cholinergic interneurons. These experiments show distinct opposite functions of muscarinic $\mathrm{M}_{1}$ - and $\mathrm{M}_{2}$-type receptors in neostriatal output, i.e., the firing of projection neurons. The results suggest that the use of more selective antimuscarinics may be more profitable for the treatment of motor deficits.

Key words: muscarinic receptors; neuromodulation; firing patterns; neostriatum; acetylcholine; Parkinson's disease; basal ganglia

sall, 1998). These ligands have not been thoroughly tested on striatal function or disease models. One reason for this is that antagonist selectivity is still weak (Caulfield and Birdsall, 1998).

However, available evidence points toward an important functional segregation between $\mathrm{M}_{1}$ - and $\mathrm{M}_{2}$-type receptors in the neostriatum; receptors of the $\mathrm{M}_{2}$ type are abundant on large interneurons (Yan and Surmeier, 1996), whereas those of the $\mathbf{M}_{1}$ type are abundant on medium-sized projection neurons (Hersch et al., 1994; Howe and Surmeier, 1995; Yan and Surmeier, 1996). In contrast, receptors of the $\mathrm{M}_{4}$ type are located on both large interneurons and projection neurons (Yan and Surmeier, 1996). Therefore, a simple hypothesis would state that activation or blockade of $\mathrm{M}_{1}$ - or $\mathrm{M}_{2}$-type receptors should lead to very different results on the output of the neostriatal circuitry, that is, the firing of the spiny projection neuron. In other words, if the segregation of $\mathrm{M}_{1}$ - and $\mathrm{M}_{2}$-type receptors has a global physiological importance, a difference in the output firing of the spiny neuron should be readily seen when either of these receptors is blocked, despite the weak selectivity of the muscarinic antagonists.

To test this hypothesis, the present work compares the actions of two reputed and relatively selective muscarinic antagonists, pirenzepine $\left(\mathrm{M}_{1}\right)$ and AF-DX $116\left(\mathrm{M}_{2}\right)$, on the excitability of the spiny projection neuron.

A preliminary report of this study has been presented in abstract form (Galarraga et al., 1998).

\section{MATERIALS AND METHODS}

The present experiments were performed on dissected rat dorsal neostriatal slices maintained in vitro as previously reported (Hernandez- 
López et al., 1997). Briefly, Wistar rats (100-200 gm) were deeply anesthetized and perfused transcardially with $50 \mathrm{ml}$ of an iced-cold $\left(4^{\circ} \mathrm{C}\right)$ solution containing (in $\mathrm{mM}$ ): $125 \mathrm{NaCl}, 3 \mathrm{KCl}, 2 \mathrm{CaCl}_{2}, 1 \mathrm{MgCl}_{2}, 25$ $\mathrm{NaHCO}_{3}, 10$ D-glucose, 0.0002 thiourea, and 0.0002 L-ascorbic acid (saturated with $95 \% \mathrm{O}_{2}$ and $5 \% \mathrm{CO}_{2} ; 300 \mathrm{mOsm} / 1 ; \mathrm{pH}=7.4$ ). The brain was rapidly removed and placed in this solution before slicing. Saggital slices ( $350 \mu \mathrm{m}$ thick) of the neostriatum were obtained in a vibratome and incubated $30 \mathrm{~min}$ at $25^{\circ} \mathrm{C}$ before recording. The slices were then transferred to a submerged recording chamber and superfused with saline of the same composition $\left(34-36^{\circ} \mathrm{C}\right)$. Intracellular recordings were performed with microelectrodes filled with $3 \mathrm{M} \mathrm{K}$-acetate and $1 \%$ biocytin (80-120 M $\Omega$ ). Records were obtained with an active bridge electrometer, digitized (Neuro Data, Cygnus Technologies) and saved on VHS tapes $(40 \mathrm{KHz})$ to be analyzed off-line with a PC clone computer. After recordings, neurons were injected with biocytin as previously described (Horikawa and Armstrong, 1988; Flores-Hernández et al., 1994). All neurons analyzed are medium spiny projection neurons.

The stimulus used was a current ramp $(0.5-1 \mathrm{nA} / \mathrm{sec}, 1 \mathrm{mV} / \mathrm{msec})$ (Jahnsen and Llinás, 1984; Uchimura and North, 1990; Bargas et al., 1994; Galarraga et al., 1994; Lee and Heckman, 1998). In current-clamp conditions a ramp response allows ready evaluation of the action of a transmitter both at the subthreshold voltage range (from approximately -100 to approximately $-40 \mathrm{mV}$ ) and during firing (Pineda et al., 1995; Pacheco-Cano et al., 1996; Lee and Heckman, 1998). Changes in the slope of the current-voltage relationship $(I-V$ plot $)$ can be interpreted as input resistance $\left(\mathrm{R}_{\mathrm{N}}\right)$ changes induced by the transmitter (Uchimura and North, 1990; Galarraga et al., 1994; Pacheco-Cano et al., 1996). The slope of the $I-V$ function used for quantitative comparisons was its derivative at resting membrane potential or zero applied current (Galarraga et al., 1994). Experiments were paired so that records in the presence and absence of drugs were compared in the same neuron and in the same sample, with a nonparametric test (Wilcoxon's $t$ test). Although not shown for the sake of figure clarity, all transmitter responses described were reversible. Means \pm SEM of $R_{N}$ changes are reported.

TTX, cesium chloride $\left(\mathrm{Cs}^{+}\right)$, cadmiun chloride $\left(\mathrm{Cd}^{2+}\right)$, physostigmine, neostigmine bromide, atropine sulfate, $N$-methyl-D-glucamine (Sigma, St. Louis, MO), muscarine, pirenzepine, 4-diphenylacetoxy- $N$ [2-chloroethyl]-piperidine (4-DAMP) (Research Biochemicals, Natick, MA) and AF-DX 116 (as a generous gift from Karl Thomae, BoehringerIngelheim, Ingelheim, Germany) were added from freshly prepared stock solutions to the bath saline. The selective $\mathrm{M}_{4}$-type receptor antagonist MT-3 was obtained from Alomone Labs (Jerusalem, Israel).

Monitoring ACh outflow in striatal slices. Changes in endogenous ACh release were quantified in brain slices similar to those used for electrophysiology ( $350 \mu \mathrm{m}$ thick), except that they were cut with a hollow punch of fixed diameter, so that all the slices used for release experiments had approximately the same size and wet weight. All slices were taken from the dorsal neostriatum and were introduced in small glass holders placed into tubes of $200 \mu \mathrm{l}$ volume where they were incubated in the same superfusion saline (bubbled with $95 \% \mathrm{O}_{2}$ and $5 \% \mathrm{CO}_{2}$ at $34-36^{\circ} \mathrm{C}$ ) in the presence of physostigmine or neostigmine $(5 \mu \mathrm{M})$. The concentration of the ACh esterase inhibitor was the same as that used in electrophysiological experiments (see Results).

The slices were then transferred to several $200 \mu \mathrm{l}$ tubes in succession for 20 min periods, either in the absence (basal outflow) or the presence of the muscarinic receptor antagonists pirenzepine and AF-DX 116. Control ACh concentration was measured in parallel chambers in the absence of any antagonist. After transferring the tissue to a new tube, the previous one was placed on ice for later processing. The amount of ACh found in the control condition (incubations in the absence of the antagonists) was compared with the incubations in the presence of the antagonists. Data from whole samples are represented with box plots (Tukey, 1977), but mean \pm SEM are reported in the text along with nonparametric comparisons (Mann-Whitney $U$ test).

ACh assay. ACh levels were measured in the superfusion saline from 20 min incubated samples. Twenty microliter samples were taken from each period and measured with an HPLC system with electrochemical detection added (BAS, West Lafayette, IA). Up to 10 samples could be measured from a single tube. Each sample was injected into a polymeric reversed phase column (BAS); ACh and choline were then converted into hydrogen peroxide and betaine in a postcolumn enzyme reactor containing immobilized acetylcholinesterase and choline oxidase. The hydrogen peroxide was detected electrochemically by a platinum electrode set at $500 \mathrm{mV}(\mathrm{vs} \mathrm{Ag} / \mathrm{AgCl})$ and $5 \mathrm{~mA}$ range. The mobile phase consisted of $50 \mathrm{~mm}$ sodium phosphate buffer, $\mathrm{pH} 8.5$, and $0.5 \%$ kathon reagent (BAS). The smallest extracellular ACh concentration ([ACh $]_{\mathrm{O}}$ ) detected was $\sim 0.1 \mathrm{pM}$ in a sample of $20 \mu \mathrm{l}$ or $[\mathrm{ACh}]_{\mathrm{O}}=5 \mathrm{~nm} / \mathrm{l}$. [ACh $]_{\mathrm{O}}$ was quantified by comparison with peak areas of standard solutions that were assayed in parallel (Gutierrez et al., 1997). Finally, [ACh $]_{\mathrm{O}}$ is expressed as $\mathrm{pm} / 20 \mu \mathrm{l}(\mathrm{pm} / \mathrm{sample})$. Note that mean $[\mathrm{ACh}]_{\mathrm{O}}$ in control conditions is 10 times the detection limit.

\section{RESULTS}

\section{Actions of muscarine and endogenous ACh}

Muscarinic actions were confirmed in medium spiny neurons of the dorsal neostriatum. As previously described, a linear current ramp injection (Fig. 1A, top) evokes a nonlinear subthreshold membrane potential response attributable, in part, to $\mathrm{Cs}^{+}$. sensitive inward rectification (Galarraga et al., 1994; Nisenbaum and Wilson, 1995; Mermelstein et al., 1998) (Fig. 1 $\mathrm{A}$, bottom). In all neurons tested $(n=77)$, muscarine $(0.5-1 \mu \mathrm{M})$ changed subthreshold response and enhanced evoked firing significantly (Fig. 1B) (Dodt and Misgeld, 1986; Pineda et al., 1995). The ascending portion of the voltage trajectory can be used to build current-voltage relationships ( $I-V$ plots), which show a change in subthreshold membrane conductance (Fig. 1C; Galarraga et al., 1994). $I-V$ plots show that muscarine produces an apparent increase in $\mathrm{R}_{\mathrm{N}}$ as measured by a change in slope (Fig. 1C; see Materials and methods) (Dodt and Misgeld, 1986; Uchimura and North, 1990; Pineda et al., 1995; Hsu et al., 1996). In eight neurons analyzed quantitatively $\left(0.5-1 \mu \mathrm{M}\right.$ muscarine), mean $\mathrm{R}_{\mathrm{N}}$ increased from $42.4 \pm 3$ to $52.4 \pm 4.5 \mathrm{M} \Omega(p<0.02$, Wilcoxon's $t$ test). This is compatible with the closing of inward rectifying $\mathrm{K}^{+}$ conductance, because $I-V$ plots cross around $-80 \mathrm{mV}$, that is, near the $\mathrm{K}^{+}$equilibrium potential (Fig. 1C). This action of muscarine remains in the presence of the selective $\mathrm{M}_{4}$-type receptor antagonist MT-3 (10 nM) (data not shown), suggesting that the receptor type involved in this response is the $\mathrm{M}_{1}$ (Olianas et al., 1996; Adem and Karlsson, 1997; Purkerson and Potter, 1998). The cholinergic actions described are reversible with washing (Pineda et al., 1995). Other concentrations of muscarine (5 and $10 \mu \mathrm{M})$ were tested with similar results, indicating that $1 \mu \mathrm{M}$ is a near-saturating concentration.

Increasing the endogenous $\mathrm{ACh}$ concentration $\left([\mathrm{ACh}]_{\mathrm{O}}\right)$ in the slice by applying the cholinesterase inhibitor physostigmine ( 5 $\mu \mathrm{M})$ had effects similar to those of muscarine: $R_{N}$ and evoked discharge were enhanced (Fig. $1 D-F$ ). A significant increase in $\mathrm{R}_{\mathrm{N}}$ was quantified in a sample of five neurons tested. Mean varied from $33.4 \pm 3.9$ to $39.7 \pm 4.5 \mathrm{M} \Omega(p<0.05$, Wilcoxon's $t$ test $)$. Neostigmine had similar effects $(n=2)$. Thus, increases in endogenous $[\mathrm{ACh}]_{\mathrm{O}}$ in slices of isolated dorsal neostriatum can be reflected in the subthreshold response and evoked discharge of the medium spiny neuron. Moreover, the effects of muscarine and endogenous ACh were the same.

Next, we explored the possibility that the effects of muscarinic receptor activation were direct on spiny neurons and not attributable to the activation of other elements in the slice. One micromolar muscarine was applied in the presence of $1 \mu \mathrm{M}$ TTX (Fig. $2 A, B$ ) to abolish neuronal activity or $400 \mu \mathrm{M} \mathrm{Cd}{ }^{2+}$ (Fig. $2 D, E)$ to reduce spontaneous synaptic actions (Flores-Hernandez et al., 1994; Bargas et al., 1998). As previously reported (Galarraga et al., 1994), TTX abolishes firing without changing the subthreshold membrane response for the ascending ramp (Fig. $2 A ;>30$ min with TTX). Nevertheless, muscarine kept changing the subthreshold trajectory and enhancing $\mathrm{R}_{\mathrm{N}}$ in the presence of TTX in each neuron tested (Fig. $2 B, C$; mean $\mathrm{R}_{\mathrm{N}}, 41 \pm 9-52.5 \pm$ $13 \mathrm{M} \Omega ; n=4) . \mathrm{Ca}^{2+}$ blockade also abolishes repetitive firing in these neurons (Galarraga et al., 1989). However, the ascending 

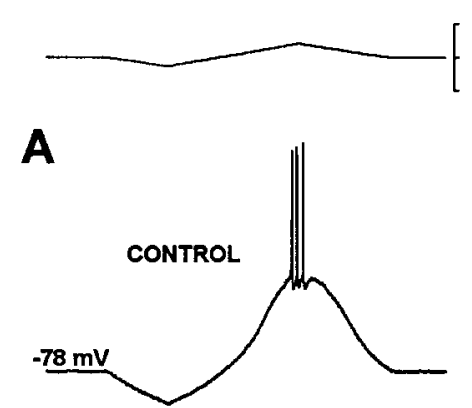

B
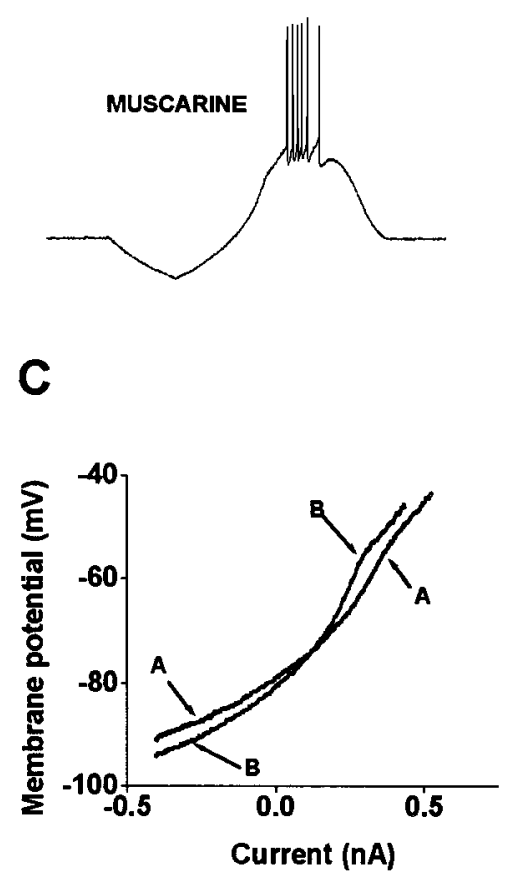
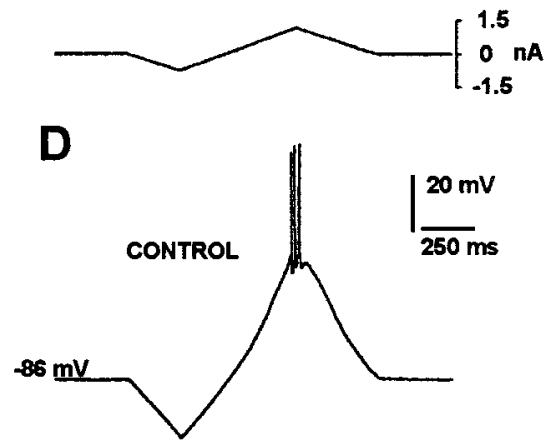

E

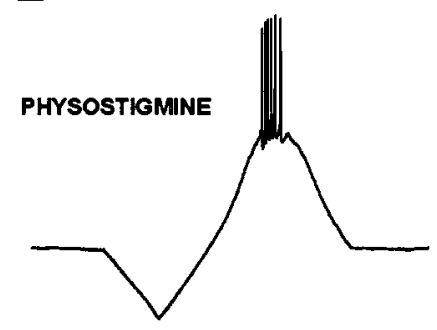

$\mathbf{F}$

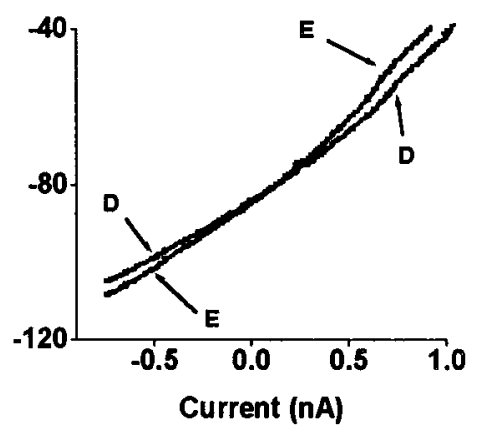

Figure 1. Cholinergic muscarinic agonists enhance firing and change subthreshold membrane properties of neostriatal medium spiny projection neurons. A, Firing is evoked with a depolarizing and linear current ramp. Note that the subthreshold voltage response to the ramp is not linear. $B$, The cholinergic muscarinic receptor agonist muscarine (1 $\mu \mathrm{M})$ enhances firing. $C$, When voltage trajectories toward firing in $A$ and $B$ are used to build current-voltage relationships ( $I-V$ plots), it is seen that muscarine increases the slope of the $I-V$ plot; that is, it increases input resistance $\left(\mathrm{R}_{\mathrm{N}}\right)$ and thus favors the depolarization toward firing. $D-F$, Similar result using the cholinesterase inhibitor physostigmine $(5 \mu \mathrm{M})$. portion of the ramp response is not significantly changed (Fig. $2 D)$. In $\mathrm{Cd}^{2+}$, muscarine kept enhancing the slope of the $I-V$ plot $\left(\mathrm{R}_{\mathrm{N}}\right)$ in all neurons tested (Fig. $2 \mathrm{D}, \mathrm{F} ; 33 \pm 5.5-42 \pm 8.4 \mathrm{M} \Omega ; n=$ 4). Pooling together all experiments in which indirect circuitry actions were blocked (TTX or $\mathrm{Cd}^{2+}$ ), the increase in $\mathrm{R}_{\mathrm{N}}$ attributable to muscarine was significant $(36.7 \pm 3.9 \mathrm{M} \Omega$ before and $46.4 \pm 5.5 \mathrm{M} \Omega$ during muscarine; $n=8 ; p<0.02$, Wilcoxon's $t$ test). Because spontaneous firing and synaptic activity have been abolished in these experiments, they suggest that muscarinic actions are direct on spiny projection neurons. However, muscarine caused a change in the $I-V$ plot trajectory in the whole subthreshold range, from -120 to $-40 \mathrm{mV}$, whereas inward rectifying conductance should be seen at more negative potentials only (more negative than approximately $-80 \mathrm{mV}$ in $\left[\mathrm{K}^{+}\right]_{\mathrm{O}}=3$ mM; Mermelstein et al., 1998; Reyes et al., 1998).

To test whether muscarinic actions at or below resting potential were attributable to inward rectifying conductances, $2 \mathrm{~mm} \mathrm{Cs}^{+}$, a blocker of these conductances, was used to block inward rectification (Mermelstein et al., 1998). The subthreshold voltage response to a current ramp is greatly altered by $\mathrm{Cs}^{+}$; the hyperpolarizing portion of the ramp response shows a larger and more sudden change for the same stimulus, caused by $\mathrm{Cs}^{+}$blockade of an inward current that normally opposes membrane hyperpolarization (Fig. 3, compare $A, B$ ). This is reflected in the $I-V$ plot as an increase in $\mathrm{R}_{\mathrm{N}}(I-V$ slope $)$ at potentials more negative than $-80 \mathrm{mV}$ (Galarraga et al., 1994; Reyes et al., 1998). The result was that the increase in $\mathrm{R}_{\mathrm{N}}$ induced by muscarine at potentials more negative than $-80 \mathrm{mV}$ was occluded in the presence of $\mathrm{Cs}^{+}$ $(n=3)$, suggesting that muscarine acts through $\mathrm{Cs}^{+}$-sensitive channels at polarized potentials. However, $\mathrm{Cs}^{+}$changes very little the membrane potential trajectory, or $\mathrm{R}_{\mathrm{N}}$, at more depolarized subthreshold potentials. Accordingly, muscarine was still able to induce an increase in $\mathrm{R}_{\mathrm{N}}$ at the more depolarized subthreshold potentials (Fig. 3B,C). Note that this action is evident even in the presence of $1 \mu \mathrm{M}$ TTX, suggesting both that apparent $\mathrm{R}_{\mathrm{N}}$ enhancement induced by muscarine at this depolarized range is not attributable to inward TTX-sensitive $\mathrm{Na}^{+}$inward currents and that the effect shown is direct (postsynaptic).

In addition to TTX, the increase in $\mathrm{R}_{\mathrm{N}}$ induced by muscarine at the more depolarized subthreshold potentials could not be blocked by $\mathrm{Ba}^{2+}, \mathrm{Cd}^{2+}$, or $\mathrm{Co}^{2+}$ (data not shown, but see Fig. $2 D-F)$. This excludes $\mathrm{Na}^{+}, \mathrm{K}^{+}$, and $\mathrm{Ca}^{2+}$ channels sensitive to these blockers as the main cause of $\mathrm{R}_{\mathrm{N}}$ increase between -70 and $-45 \mathrm{mV}$. However, the change in $\mathrm{R}_{\mathrm{N}}$ induced by muscarine at 

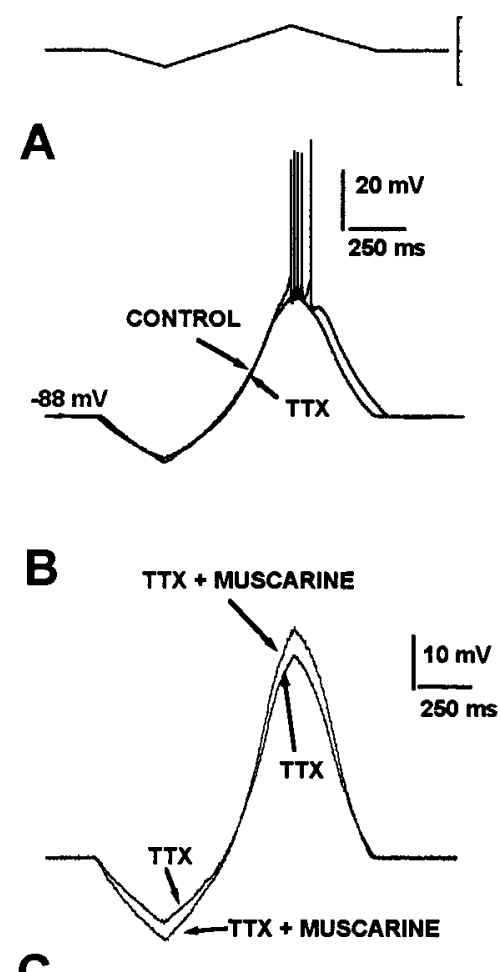

C

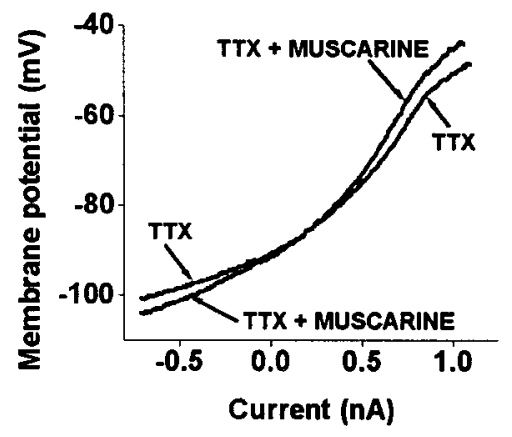

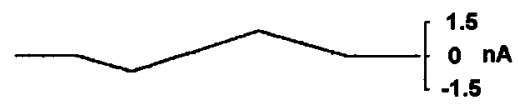

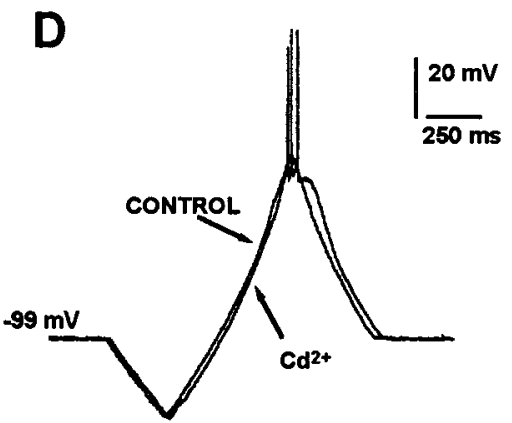

E
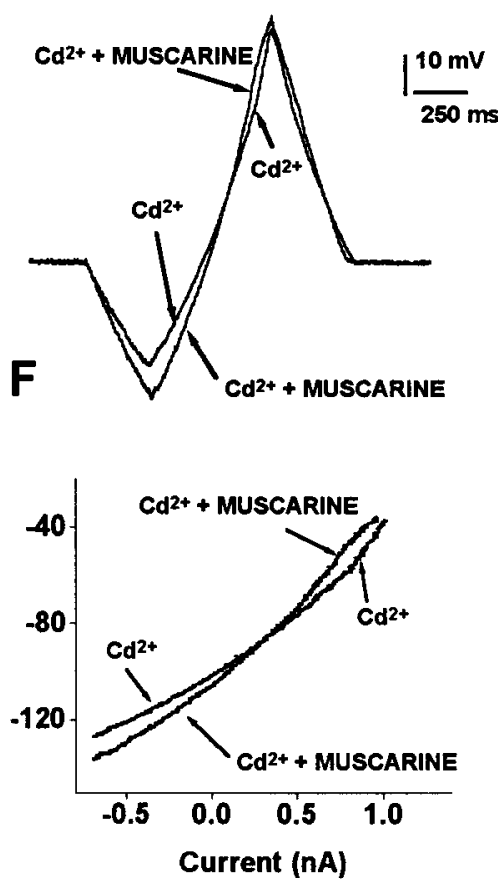

Figure 2. Muscarinic facilitatory actions are direct. $A$, Firing is evoked with a current ramp (top). One micromolar TTX blocks the evoked firing but does not change the ascending voltage trajectory. $B$, Muscarine changes the ascending voltage trajectory in the presence of TTX. $C, I-V$ plots show that $1 \mu \mathrm{M}$ muscarine increases $\mathrm{R}_{\mathrm{N}}$ in the presence of TTX. $D-F$, Similar experiment shows that $1 \mu \mathrm{M}$ muscarine increases $\mathrm{R}_{\mathrm{N}}$ in the presence of 400

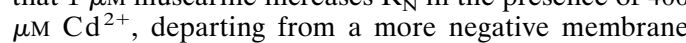
potential.

these more depolarized potentials could be blocked by superfusing the slice in a low $\mathrm{Na}^{+}$saline (Fig. 3D-F; N-methyl-Dglucamine-Cl substituted for $125 \mathrm{~mm} \mathrm{NaCl}$ ). In contrast, the change in $\mathrm{R}_{\mathrm{N}}$ induced by muscarine at polarized potentials (more negative than $-80 \mathrm{mV}$ ) was still present in low $\mathrm{Na}^{+}$(Fig. $3 F ; n=$ 3 ; $\mathrm{Cs}^{+}$was absent). These experiments show that although muscarine induces a change in the voltage trajectory and $\mathrm{R}_{\mathrm{N}}$ in the whole subthreshold range (between -100 and $-40 \mathrm{mV}$ ), $\mathrm{Cs}^{+}$ blocks this action only at polarized potentials (more negative than $-80 \mathrm{mV}$ ), whereas a low $\mathrm{Na}^{+}$saline is the procedure that blocks this action at potentials nearer to the firing threshold (between -70 and $-40 \mathrm{mV}$ ). This suggests that muscarinic action on the subthreshold response is not attributable to a single ion conductance.

\section{Actions of $\mathrm{ACh}$ receptor antagonist}

As shown in Figure 4, 25-100 nm pirenzepine, a relatively selective muscarinic $\mathrm{M}_{1,4}$-type receptor antagonist, completely blocked all muscarinic actions on the subthreshold response (Fig. $4 A-G$ ). Pirenzepine had no action by itself (Figs. $4 A, E, 5 D$ ), but it blocked the postsynaptic effects of $1 \mu \mathrm{M}$ muscarine (Fig. $4 B, F$ ), which were recovered when the $\mathrm{M}_{1,4}$ receptor antagonist was removed (Fig. 4D, $G ; n=4)$. Neither AF-DX 116 (see Fig. 7) a selective blocker of $\mathrm{M}_{2}$-type receptors, nor 4-DAMP (data not shown), a selective blocker of $\mathrm{M}_{3,4}$-type receptors, could block the muscarinic actions on the spiny neuron. Because the antagonistic action of AF-DX 116 exerts overlapping effects on both $\mathrm{M}_{2}$ and $\mathrm{M}_{4}$ receptors (Caulfield and Birdsall, 1998), and the muscarinic action remains in the presence of MT-3, it was concluded that these muscarinic facilitatory effects are more probably mediated through $\mathrm{M}_{1}$-type receptors, which are abundant on spiny neurons but present in a lesser percentage on the cholinergic interneurons (Hersch et al., 1994; Yan and Surmeier, 1996).

Previous evidence has shown that ACh may modulate (decrease) its own release in the neostriatum (Consolo et al., 1987; Weiler, 1989), probably through the activation of $\mathbf{M}_{2}$-type muscarinic autoreceptors located in the cholinergic interneurons (Hersch et al., 1994; Yan and Surmeier, 1996). And because it has been shown that endogenous ACh is readily detected by the spiny neuron membrane (see above), we tested the idea that the increase in endogenous $\mathrm{ACh}$ release induced by $\mathrm{M}_{2}$ receptor blockade is able to modulate the membrane responses of neostriatal output neurons. This would demonstrate a direct action of cho- 

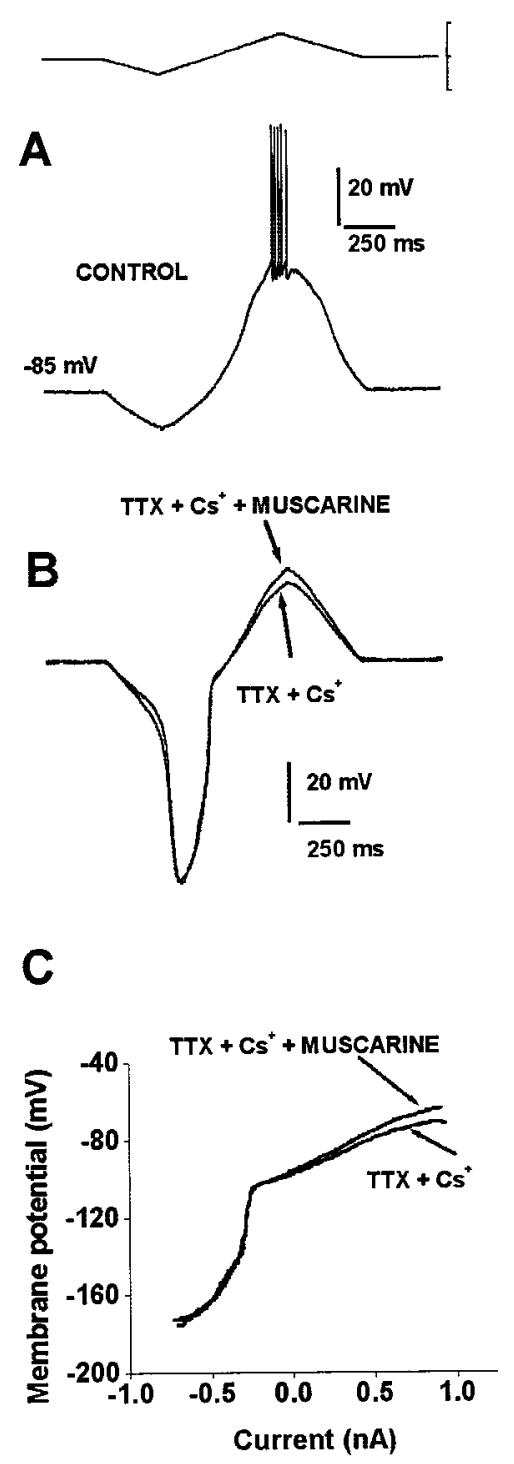
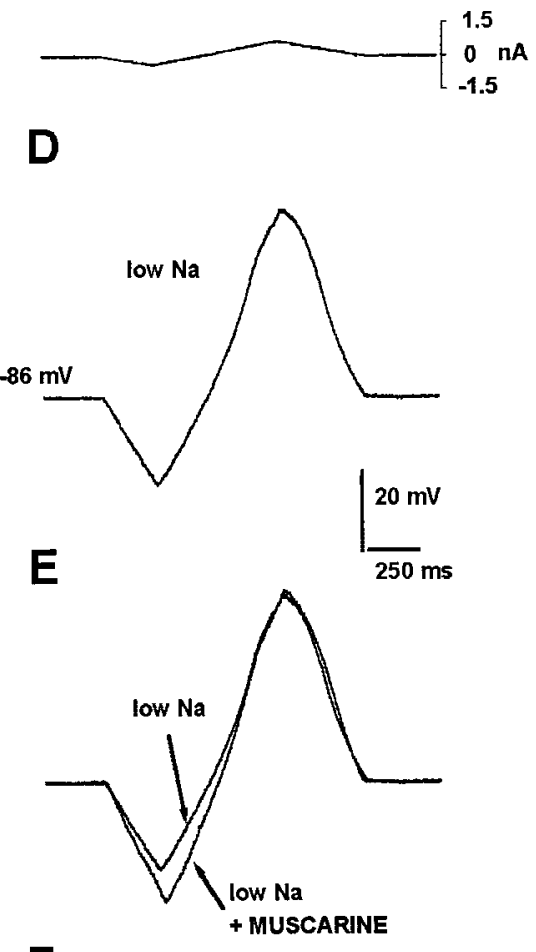

$\mathbf{F}$

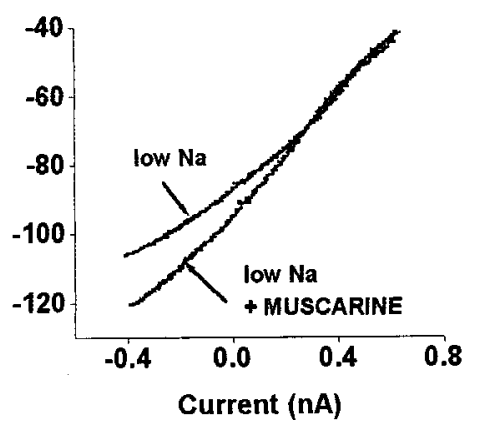

Figure 3. Different conductances are affected by muscarine at different membrane potentials in the subthreshold range. $A$, Firing is evoked by a current ramp. $B$, In the presence of $2 \mathrm{mM} \mathrm{Cs}^{+}$, inward rectification produced at polarized potentials is blocked. However, a great increase in the rate of change of the voltage trajectory at this potential range is evident (Galarraga et al., 1994). One micromolar muscarine is no longer able to change the ascending voltage trajectory at polarized potentials in the presence of $\mathrm{Cs}^{+}$. However, muscarine still changes the voltage trajectory at potentials nearer the firing threshold. One micromolar TTX abolished firing in this experiment. $C$, Muscarine is no longer able to change $\mathrm{R}_{\mathrm{N}}(I-V$ slope $)$ at polarized potentials in the presence of $\mathrm{Cs}^{+}$, but it is still able to change $\mathrm{R}_{\mathrm{N}}$ at potentials nearer the firing threshold. $D$, Subthreshold voltage response to a current ramp in a low- $\mathrm{Na}^{+}$saline. $E$, In this condition, muscarine is still able to change the ascending voltage trajectory in the most polarized voltage range, but it is no longer able to change the voltage trajectory near the firing threshold. $F, I-V$ plots show that in low $\mathrm{Na}^{+}$, muscarine changes $\mathrm{R}_{\mathrm{N}}$ only in the most polarized voltage range (more negative than $-80 \mathrm{mV})$. linergic interneurons on spiny projection neurons attributable to muscarinic $\mathrm{M}_{2}$ receptor blockade.

Figure 5 shows that bath application of 50-100 nм concentrations of the relatively selective $\mathrm{M}_{2}$ receptor antagonist AF-DX 116 increases the firing response of spiny neurons to the same stimulus (Fig. 5A,B). This response was always followed by an increase in $\mathrm{R}_{\mathrm{N}}$.

Mean $\mathrm{R}_{\mathrm{N}}$ changed from $31.7 \pm 1.7$ to $38.8 \pm 1.52 \mathrm{M} \Omega(n=7$; $p<0.02$; Wilcoxon's $t$ test). Therefore, the blockade of an $\mathrm{M}_{2}$-type receptor mimicked the activation of an $\mathrm{M}_{1}$-type receptor, revealing a functional antagonism between $M_{1}$ and $M_{2}$ types of muscarinic receptors on the neostriatal output. To test whether this action could be imputed to an increase in the slice $[\mathrm{ACh}]_{\mathrm{O}}$ attributable to $\mathrm{M}_{2}$ autoreceptor blockade, HPLC measurements (with electrochemical detection) were performed in slices similar to those used for electrophysiology. These slices were exposed to concentrations of muscarinic receptor antagonists similar to those used in electrophysiological experiments and compared with those maintained in control saline (see Materials and Methods). Figure $5 D$ shows box plots that demonstrate that the blocking of presynaptic muscarinic autoreceptors by the selective $\mathrm{M}_{2}$ receptor antagonist AF-DX $116(50-100 \mathrm{nM})$ leads to an increase in endogenous ACh release in the slice. Mean ACh concentration increased significantly from $1.47 \pm 0.25(n=22)$ to $3.72 \pm 0.65$ $\mathrm{pM} / 20 \mu \mathrm{l}(n=12)(p<0.002$, Mann-Whitney $U$ test $)$. In contrast, incubation with pirenzepine had no significant effect on $\mathrm{ACh}$ efflux: $1.37 \pm 0.26 \mathrm{pm} / 20 \mu \mathrm{l}$. These experiments support previous evidence on the existence of a neostriatal cholinergic feedback mediated by autoreceptors (Consolo et al., 1987; Weiler, 1989) and show that this mechanism can be readily demonstrated in slices used for electrophysiology. Therefore, it is sufficient to explain the electrophysiological results; that is, interaction between cholinergic interneurons and projection neurons could be demonstrated in vitro because the released $\mathrm{ACh}$ attributable to autoreceptor blockade was able to induce an increase in the evoked discharge of the output neuron. These experiments also show that despite the weak selectivity of the muscarinic receptor antagonists, they can show significant functional differences between the activation of $\mathrm{M}_{1}$ - or $\mathrm{M}_{2}$-type receptors when used at low saturating concentrations.

As shown in Figure 6, the indirect action of the relatively selective $\mathrm{M}_{2}$-type receptor antagonist AF-DX $116(100 \mathrm{nM})$ on the firing and $\mathrm{R}_{\mathrm{N}}$ of spiny neurons can be blocked by the relatively selective $\mathrm{M}_{1,4}$ receptor antagonist pirenzepine (100 nM; $\left.n=3\right)$. 
Figure 4. Pirenzepine, an $\mathrm{M}_{1}$-like receptor antagonist, blocks the action of muscarine on firing and $\mathrm{R}_{\mathrm{N}}$. $A$, Firing is evoked with a current ramp. $B$, When 50 nM pirenzepine is added to the superfusion, firing is not significantly changed. $R_{N}$ is not changed by pirenzepine $(E)$, which virtually has no action by itself. $C$, When $1 \mu \mathrm{M}$ muscarine is added in the presence of pirenzepine, no change in firing rate or $\mathrm{R}_{\mathrm{N}}(F)$ is produced. $D$, When pirenzepine is washed off, leaving muscarine in the bathing saline, the usual effects of the cholinergic agonist are manifest: enhancement of the firing rate and increase in $\mathrm{R}_{\mathrm{N}}(G)$. Axes in $F$ (voltage) and $G$ (current) apply to all $I-V$ plots $(E-G)$.

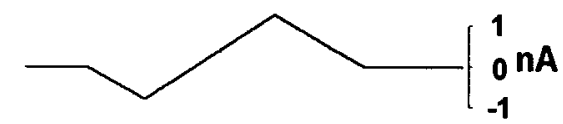

A

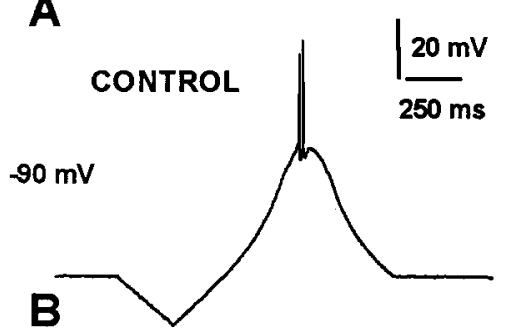

E
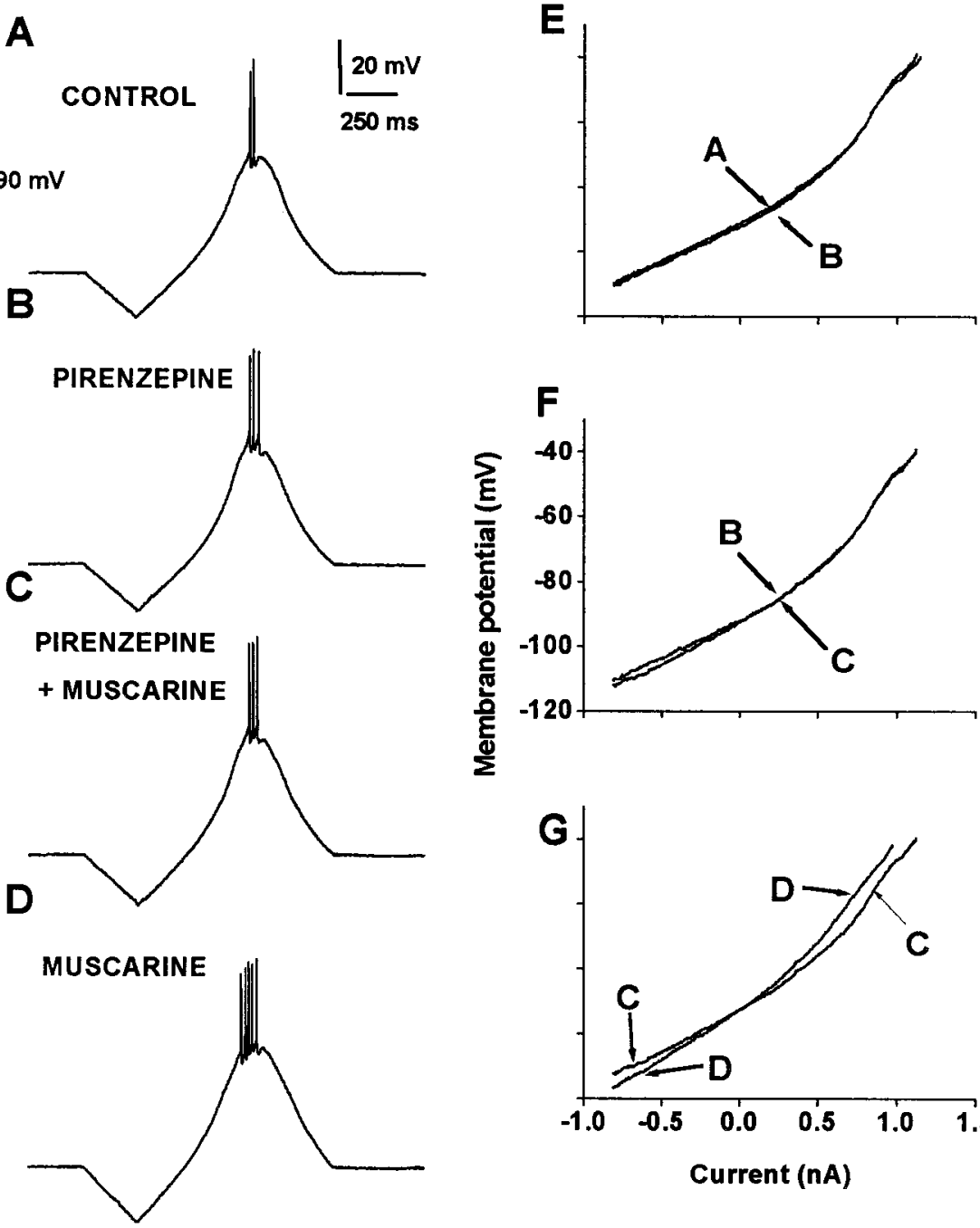
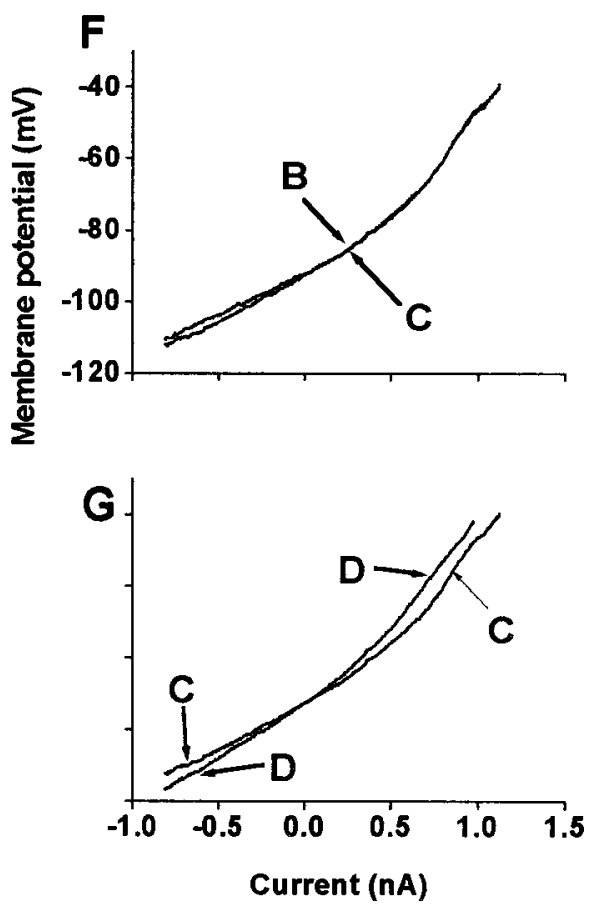

This further shows a functional antagonism between the actions of $\mathrm{M}_{1}$ - and $\mathrm{M}_{2}$-type receptors (see Discussion) in the neostriatal microcircuitry and, in particular, on the firing of the output neuron. The action of endogenous ACh is not saturating in these conditions, because the addition of muscarine produces a further increase in firing and $\mathrm{R}_{\mathrm{N}}$ (Fig. 7). Figure 7 also shows that $\mathrm{M}_{2}$-type receptor antagonists are unable to block the effect of muscarine on the firing and subthreshold $\mathrm{R}_{\mathrm{N}}$ of the output neuron. On the contrary, the effects of agonist and antagonist are synergistic.

\section{DISCUSSION}

Given the weak selectivity of available muscarinic antagonists (Caulfield and Birdsall, 1998) and the failure to clearly impute physiological actions to a single type of muscarinic receptor in many systems (e.g., Hernández-Echeagaray et al., 1999), it is reassuring to find out that a clear-cut distinction between the actions of $\mathrm{M}_{1}$ - and $\mathrm{M}_{2}$-type receptors can be observed in the neostriatal output neuron (see below). This finding is important because the activity of the spiny neurons is the final output of the circuit and the basis of all pathophysiological models that are basic for understanding the therapeutics for Parkinson's disease and other motor deficits.

Given that the muscarinic receptor antagonists that were used are not very selective (Caulfield and Birdsall, 1998), the contrasting actions described in this work support the main hypothesis, i.e., the functional segregation of $\mathrm{M}_{1}$ - and $\mathrm{M}_{2}$-type receptors in the neostriatal microcircuitry. The experiments show that two relatively selective antagonists for $\mathrm{M}_{1,4^{-}}$and $\mathrm{M}_{2}$-type receptors (Caulfield and Birdsall, 1998), pirenzepine and AF-DX 116, respectively, have clear opposite actions on the output of the microcircuitry: whereas pirenzepine blocks, AF-DX 116 mimics and augments (but does not block) the enhanced excitability produced by muscarine. Because $\mathrm{M}_{4}$-type receptors are present in both large cholinergic interneurons and medium-sized projection neurons (Weiner et al., 1990; Hersch et al., 1994; Yan and Surmeier, 1996), and AF-DX 116 also has some affinity for $\mathrm{M}_{4}$-type receptors, it is then posited that the sharp opposite actions found between pirenzepine and AF-DX 116 have to be attributed to different locations and actions of $\mathrm{M}_{1}$ - and $\mathrm{M}_{2}$-type receptors. Hence, they can hardly be assigned to the actions of the 


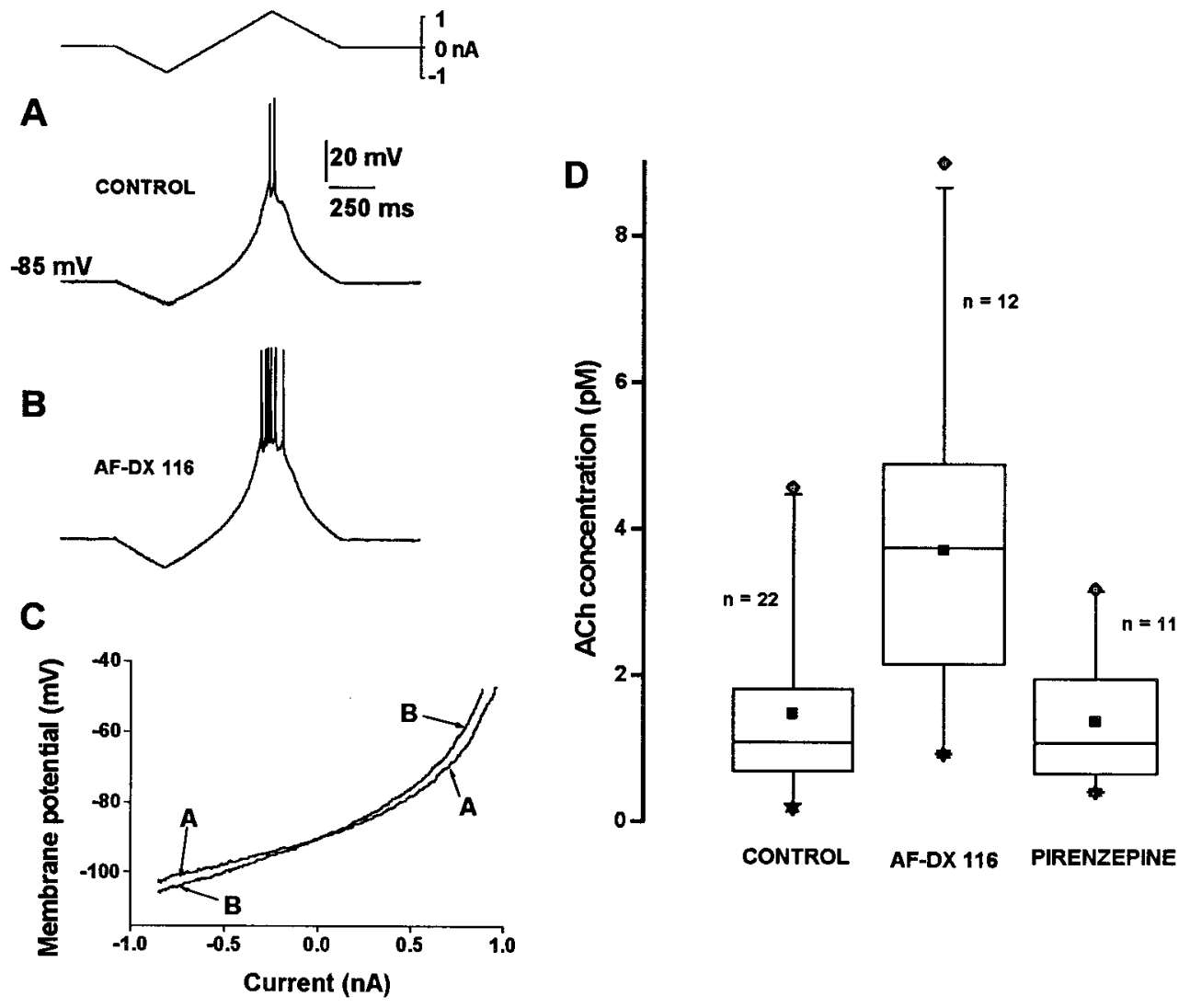

Figure 5. AF-DX 116, an $\mathrm{M}_{2}$-like receptor antagonist, mimics the action of muscarine on firing and $\mathrm{R}_{\mathrm{N}}$ and increases the release of $\mathrm{ACh}$ as measured by HPLC. $A$, Firing is evoked by a current ramp. $B$, Firing is enhanced when $100 \mathrm{~nm}$ AF-DX 116 is added to the superfusion. $C, \mathrm{R}_{\mathrm{N}}$ is increased during AF-DX 116. $D$, Using slices similar to those used for intracellular recordings, HPLC determinations of ACh concentrations were done under three conditions: control, in the presence of AF-DX 116 , and in the presence of pirenzepine. Box plots depict whole sample distributions in the three cases. ACh concentration is significantly higher when AF-DX 116 is present in the bath, showing that AF-DX 116 increases the endogenous ACh release.
$\mathrm{M}_{4}$-type receptor. This last inference is supported by the fact that the facilitatory muscarinic action persists in the presence of MT-3, a selective peptidic toxin against the $\mathrm{M}_{4}$-type receptor.

It is concluded that the $\mathrm{M}_{1}$-type receptor action, i.e., the increase in discharge and $\mathrm{R}_{\mathrm{N}}$ of spiny neurons (Dodt and Misgeld, 1986; Pineda et al., 1995), is direct or postsynaptic, because neither $\mathrm{Cd}^{2+}$ nor TTX applied to the bathing saline could abolish the effects on $\mathrm{R}_{\mathrm{N}}$, and this last action has been reported on dissociated neurons (Hsu et al., 1996). The above conclusion is supported by previous evidence that indicates that neostriatal $\mathrm{M}_{1}$-type receptors are found abundantly on spiny projection neurons and much less on cholinergic interneurons (Weiner et al., 1990; Hersch et al., 1994; Yan and Surmeier, 1996). In addition, only pirenzepine but not AF-DX 116 or 4-DAMP could block these postsynaptic effects when administered at nanomolar concentrations. Moreover, it has been reported that muscarinic activation preferentially enhances GABA release from neostriatal projection neurons (Kayadjanian et al., 1994; Harsing and Zigmond, 1998).

In contrast, $\mathrm{M}_{2}$-type receptors are abundant in cholinergic interneurons and less on projection neurons (Weiner et al., 1990; Hersch et al., 1994; Yan and Surmeier, 1996). Cholinergic interneurons exhibit spontaneous firing and probably maintain a tonic $[\mathrm{ACh}]_{\mathrm{O}}$ in the neostriatum (Consolo et al., 1987; Wilson et al., 1990; Kawaguchi, 1992). Thus, the location of the $\mathbf{M}_{2}$-type receptors makes them suitable to function as autoreceptors to regulate firing and ACh release by the interneurons (Weiler, 1989; Hersch et al., 1994). In agreement with this hypothesis, the present experiments show that the preferential blockade of $\mathrm{M}_{2}$-type receptors by AF-DX 116 increases the release of endogenous ACh and that this release augments the excitability of spiny projection neurons. The facilitation was mediated by $\mathrm{M}_{1}$-type receptors because the effects of AF-DX 116 could be blocked by pirenzepine. That is, a receptor antagonist blocked the action of another receptor antagonist, evidencing the mainly presynaptic and mainly postsynaptic actions of $\mathrm{M}_{2}-$ and $\mathrm{M}_{1}$-type receptors, respectively.

The experiments demonstrate the interaction between the activity of the cholinergic interneuron and the excitability of the projection neuron in the neostriatal microcircuitry. They show that an autoregulation of the cholinergic tone is continuously modulating the output of the projection neuron. It is known that the firing of the projection neuron releases substance $P$ from axon collaterals and that this peptide increases the firing of the cholinergic interneuron (Aosaki and Kawaguchi, 1996; Galarraga et al., 1999). It is also known that both projection and cholinergic interneurons are activated by neostriatal afferents (Wilson, 1998). Thus, in physiological conditions, an excess of ACh released by an active module (Graybiel et al., 1994) would be autoregulated by $\mathrm{M}_{2}$ autoreceptors. They would shut down the firing of the cholinergic interneuron at the moment of maximal concurrent firing (Graybiel et al., 1994) and may also participate in the presynaptic inhibition of the afferent input (Bargas et al., 1998; HernandezEcheagaray et al., 1999). This tuning may be critical for motor control, because the action of antimuscarinic drugs on facilitating dopaminergic activation of neuronal activity, motor behavior, and substance P expression is well known (e.g., Hernández-López et al., 1997; Wang and McGinty, 1997; Galarraga et al., 1999). We propose that this mechanism would regulate the level of activation of a given output module.

Finally, it is important to emphasize what is not shown by the present experiments. On the one hand, the actions of the $\mathrm{M}_{4}$-type 


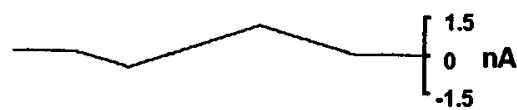

A

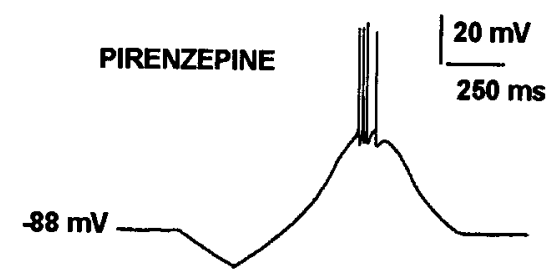

B
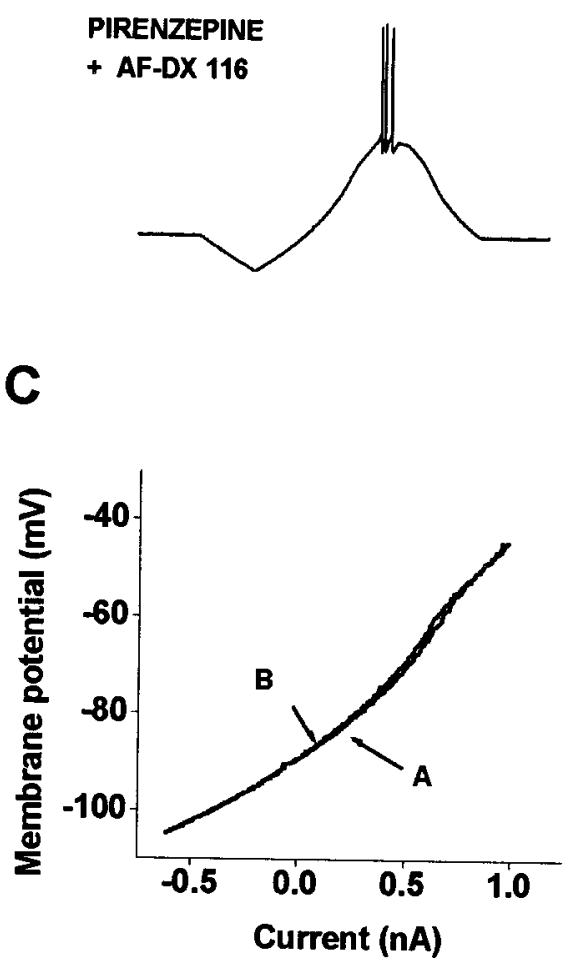

Figure 6. Pirenzepine blocks the effects of AF-DX 116. $A$, Firing is evoked with a current ramp in the presence of $100 \mathrm{~nm}$ pirenzepine. $B$, One hundred nanomolar AF-DX 116 is no longer able to mimic the actions of muscarine in the presence of pirenzepine. $C$, No change in $\mathrm{R}_{\mathrm{N}}$ is seen after AF-DX 116 when pirenzepine is present.

receptor in shaping the firing pattern of the projection neuron remain unknown. In a similar way, the actions of dopaminergic $\mathrm{D}_{1}$ receptor activation on the spiny neuron are better known than the actions of $D_{2}$ receptor activation (Surmeier et al., 1995; Hernández-López et al., 1997). On the other hand, the interaction between dopaminergic and cholinergic receptor activation is far from being understood. What is known may predict both synergistic and antagonistic actions during firing. For example, both dopamine and ACh would inhibit $\mathrm{N}$ - and $\mathrm{P} / \mathrm{Q}$-type $\mathrm{Ca}^{2+}$ currents (Howe and Surmeier, 1995; Surmeier et al., 1995). Because these currents activate the $\mathrm{K}^{+}$currents that generate the afterhyperpolarizing potential (AHP) (Vilchis et al., 1998; Bargas et al., 1999), it may be predicted that both dopamine and ACh will be synergistic in reducing the AHP and increasing the firing fre-
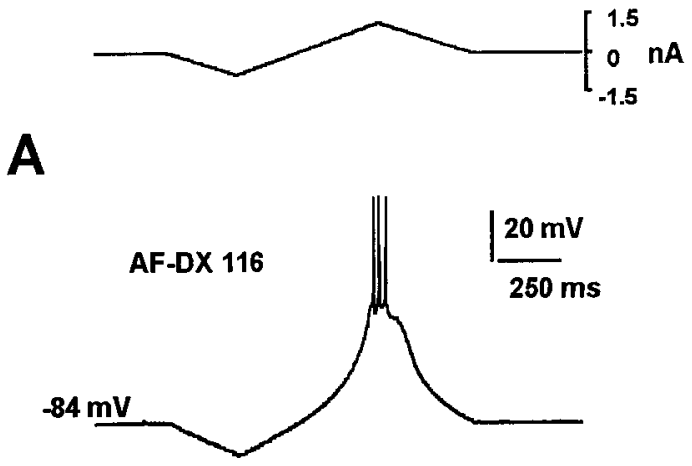

B
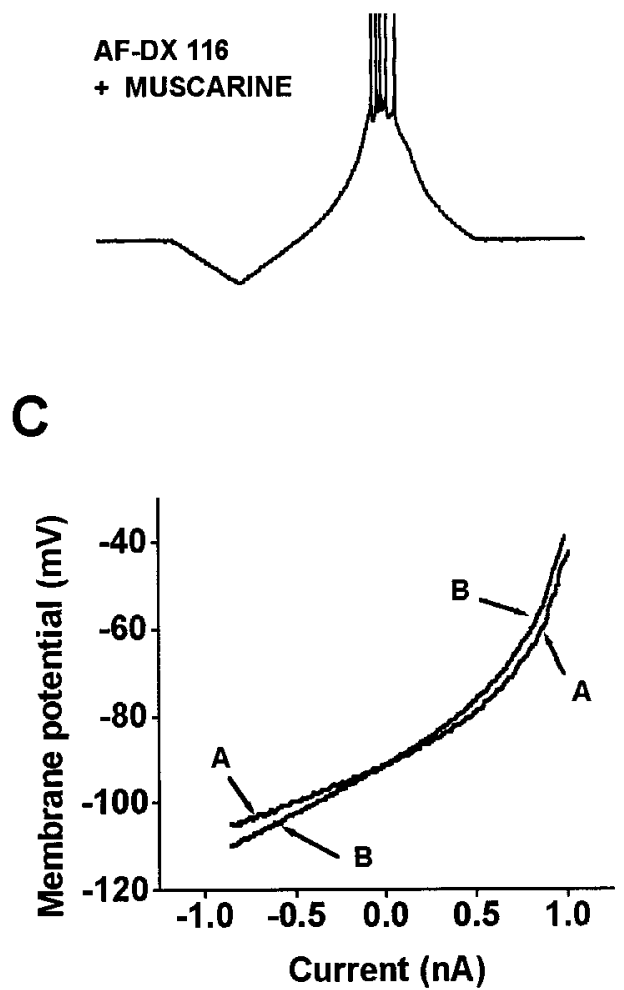

Figure 7. The effects of AF-DX 116 are far from saturation, because the addition of muscarine produces an additional enhancement of the response. $A$, Firing is evoked with a current ramp in the presence of $100 \mathrm{~nm}$ AF-DX 116. $B$, One micromolar muscarine produces an increase in firing frequency, showing that $\mathrm{M}_{2}$ antagonists do not block this response and that the effects of $100 \mathrm{nM}$ AF-DX 116 are not saturating. $C$, Muscarine also produces a further increase in $R_{N}$ in the presence of AF-DX 116 .

quency. However, ACh decreases L-type $\mathrm{Ca}^{2+}$ current and inward rectification, whereas dopamine enhances both (Howe and Surmeier, 1995; Surmeier et al., 1995; Hsu et al., 1996; PachecoCano et al., 1996; Cepeda et al., 1998; Galarraga et al., 1999). It has been shown that the L-type $\mathrm{Ca}^{2+}$ channel maintains sustained firing (Hernández-López et al., 1997). Therefore, in these cases the transmitters may be antagonistic. To conclude, more experimental evidence is needed to make a reliable model on cholinergic-dopaminergic interactions at the cell-firing level.

\section{Physiological consequences}

If an $\mathrm{M}_{2}$-type receptor antagonist leads to an increased excitability of the projection neuron, which can be blocked by an $\mathrm{M}_{1}$-type 
receptor antagonist, a question is raised about the use of nonselective antimuscarinic drugs in therapeutics and animal models of motor deficits.

The antagonists used in therapeutics and many behavioral and physiological studies are nonselective. Thus, it is not surprising that the antimuscarinic treatment has not been very reliable (e.g., Kopin, 1993; Riederer et al., 1993). Nevertheless, a sharp distinction between the actions of available $\mathrm{M}_{1}$ - and $\mathrm{M}_{2}$-type receptor antagonists can be readily demonstrated on the neostriatal output. Therefore, based on the present work, we predict that the use of more selective antimuscarinics will be more profitable for the therapy of Parkinson's disease and other motor deficits (Caulfield and Birdsall, 1998). A functional question originated by the present experiments is which of the two classes of antagonists would act synergistically with L-DOPA or other dopaminergic agonists. It would be hard to answer this question a priori.

\section{The cholinergic facilitation of the neostriatal projection neuron}

An enhancement on the excitability of spiny neurons by muscarinic activation has been well documented (Dodt and Misgeld, 1986; Pineda et al., 1995; Galarraga et al., 1999). A common finding has been an increase in $\mathrm{R}_{\mathrm{N}}$. Inward rectification is known to be present at potentials more negative than approximately -70 or $-80 \mathrm{mV}$ (depending on $\left[\mathrm{K}^{+}\right]_{\mathrm{O}}$ ) (Galarraga et al., 1994; Nisenbaum and Wilson, 1995; Mermelstein et al., 1998; Reyes et al., 1998). This work shows that, in fact, the blockade of this $\mathrm{Cs}^{+}{ }_{-}$ sensitive conductance abolishes the muscarinic actions on $R_{N}$ at this voltage range. However, at more positive potentials (more positive than $-70 \mathrm{mV}$ ), muscarinic activation still produces an increase in $I-V$ slope that is not blocked by $\mathrm{Cs}^{+}, \mathrm{Cd}^{2+}$, TTX, or $\mathrm{Co}^{2+}$. These muscarinic effects could only be occluded by reducing $\left[\mathrm{Na}^{+}\right]_{\mathrm{O}}$. This occlusion was manifest even if the muscarinic action at potentials more negative than $-80 \mathrm{mV}$ was still present (in the absence of $\mathrm{Cs}^{+}$). Taken together, the experiments suggest that muscarinic actions on excitability target several ion conductances, and one of them may be cationic (Inoue and Kuriyama, 1991; Shen and North, 1992; Howe and Surmeier, 1995; Pineda et al., 1995; Haj-Dahmane and Andrade, 1996; Hsu et al., 1996; Klink and Alonso, 1997). Note that effects on $\mathrm{Na}^{+}$currents have not been discarded by TTX blockade. It is only suggested that TTX-sensitive $\mathrm{Na}^{+}$currents are not necessary for the main subthreshold actions described here. More experiments are necessary to address this issue specifically.

In conclusion, as in the case of dopamine (Cepeda and Levine, 1998), cholinergic activity within the neostriatum involves many targets in the same neuron and several targets in different neurons of the microcircuitry. More experimentation is needed to elucidate these actions completely and to correlate them with the clinical and behavioral levels.

\section{REFERENCES}

Adem A, Karlsson E (1997) Muscarinic receptor subtype selective toxins. Life Sci 60:1069-1076.

Aosaki T, Kawaguchi Y (1996) Actions of substance P on rat neostriatal neurons in vitro. J Neurosci 16:5141-5153.

Bargas J, Galarraga E (1995) Firing response modulation in neostriatal projection neurons by cholinergic and dopaminergic agonists. In: Molecular and cellular mechanisms of neostriatal neurons (Ariano MA, Surmeier DJ, eds), pp 183-191. Austin, TX: Landes.

Bargas J, Howe A, Eberwine J, Cao Y, Surmeier DJ (1994) Cellular and molecular characterization of $\mathrm{Ca}^{2+}$ currents in acutely isolated, adult rat neostriatal neurons. J Neurosci 14:6667-6686.

Bargas J, Ayala GX, Hernandez E, Galarraga E (1998) $\mathrm{Ca}^{2+}$-channels involved in neostriatal glutamatergic transmission. Brain Res Bull 45:521-524.

Bargas J, Ayala, GX, Vilchis C, Pineda JC, Galarraga E (1999) $\mathrm{Ca}^{2+}$. activated outward currents in neostriatal neurons. Neuroscience 88:479-488.

Caulfield MP, Birdsall NJM (1998) Classification of muscarine acetylcholine receptors. Pharmacol Rev 50:279-290.

Cepeda C, Levine MS (1998) Dopamine and N-methyl-D-aspartate receptor interactions in the neostriatum. Dev Neurosci 20:1-18.

Cepeda C, Colwell CS, Itri JN, Chandler SH, Levine MS (1998) Dopaminergic modulation of NMDA-induced whole-cell currents in neostriatal neurons in slice: contribution of calcium conductances. J Neurophysiol 79:82-94.

Consolo S, Ladinsky H, Vinci R, Palazzi E, Wang J (1987) An in vivo pharmacological study on muscarinic receptor subtypes regulating cholinergic neurotransmission in rat striatum. Biochem Pharmacol 36:3075-3077.

Dodt HU, Misgeld U (1986) Muscarinic excitation and muscarinic inhibition of synaptic transmission in the rat neostriatum. J Physiol (Lond) 380:593-603.

Flores-Hernández J, Galarraga E, Pineda JC, Bargas J (1994) Patterns of excitatory and inhibitory synaptic transmission in the rat neostriatum as revealed by 4-AP. J Neurophysiol 72:2246-2256.

Galarraga E, Bargas J, Sierra A, Aceves J (1989) The role of calcium in the repetitive firing of neostriatal neurons. Exp Brain Res 75:157-168.

Galarraga E, Pacheco-Cano MT, Flores-Hernández J, Bargas J (1994) Subthreshold rectification in neostriatal spiny projection neurons. Exp Brain Res 100:239-249.

Galarraga E, Hernández-López S, Vilchis C, Miranda MI, Reyes A, Bermudez-Rattoni F, Bargas J (1998) Functional antagonism between muscarinic receptor antagonists in the neostriatum. Soc Neurosci Abstr 24:1640.

Galarraga E, Hernández-López S, Tapia D, Reyes A, Bargas J (1999) Action of substance P (neurokinin-1) receptor activation on rat neostriatal projection neurons. Synapse, in press.

Graybiel AM, Aosaki T, Flaherty AW, Kimura M (1994) The basal ganglia and adaptive motor control. Science 265:1826-1831.

Gutierrez H, Miranda MI, Bermudez-Rattoni F (1997) Learning impairment and cholinergic deafferentation after cortical nerve growth factor deprivation. J Neurosci 17:3796-3803.

Haj-Dahmane S, Andrade R (1996) Muscarinic activation of a voltagedependent cation nonselective current in rat association cortex. J Neurosci 16:3848-3861.

Harsing LG, Zigmond MJ (1998) Postsynaptic integration of cholinergic and dopaminergic signals on medium-sized GABAergic projection neurons in the neostriatum. Brain Res Bull 45:607-613.

Hernández-Echeagaray E, Galarraga E, Bargas J (1999) 3- $\alpha$-Chloroimperialine, a potent blocker of cholinergic presynaptic modulation of glutamatergic afferents in the rat neostriatum. Neuropharmacology 37:1493-1502.

Hernández-López S, Bargas J, Surmeier DJ, Reyes A, Galarraga E (1997) $\mathrm{D}_{1}$ receptor activation enhances evoked discharge in neostriatal medium spiny neurons by modulating an L-type $\mathrm{Ca}^{2+}$ conductance. J Neurosci 17:3334-3342.

Hersch SM, Gutekunst C, Rees HD, Heilman CJ, Levey AI (1994) Distribution of $\mathrm{m} 1-\mathrm{m} 4$ muscarinic receptor proteins in the rat striatum: light and electron microscopic immunocytochemistry using subtypespecific antibodies. J Neurosci 14:3351-3363.

Horikawa A, Armstrong WE (1988) A versatile means of intracellular labeling: injection of biocytin and its detection with avidin conjugates. J Neurosci Methods 25:1-11.

Howe A, Surmeier DJ (1995) Muscarinic receptors modulate N-, P-, and L-type $\mathrm{Ca}^{2+}$ currents in rat striatal neurons through parallel pathways. J Neurosci 15:458-469.

Hsu KS, Yang CH, Huang CC, Gean PW (1996) Carbachol induces inward current in neostriatal neurons through $\mathrm{M}_{1}$-like muscarinic receptors Neuroscience 73:751-760.

Inoue M, Kuriyama H (1991) Muscarinic receptor is coupled with a cation channel through a GTP-binding protein in guinea-pig chromaffin cells. J Physiol (Lond) 436:511-529.

Jahnsen H, Llinás R (1984) Electrophysiological properties of guineapig thalamic neurones: an in vitro study. J Physiol (Lond) 349:205-226.

Kawaguchi Y (1992) Large aspiny cells in the matrix of the rat neostriatum in vitro: physiological identification, relation to the compartments and excitatory postsynaptic currents. J Neurophysiol 67:1669-1682. 
Kayadjanian N, Gioanni H, Menetrey A, Besson MJ (1994) Musacrinic receptor stimulation increases the spontaneous $\left[{ }^{3} \mathrm{H}\right]$ GABA release in the rat substantia nigra through muscarinic receptors localized on sitriatonigral terminals. Neuroscience 63:989-1002.

Klink R, Alonso A (1997) Ionic mechanisms of muscarinic depolarization in entorhinal cortex layer II neurons. J Neurophysiol 77:1829-1843.

Kopin LJ (1993) Parkinson's disease: past, present and future. Neuropsychopharmacology 9:1-12.

Lee RH, Heckman CJ (1998) Bistability in spinal motoneurons in vivo: systematic variations in rhythmic firing patterns. J Neurophysiol 80:572-582.

Mermelstein PG, Song WJ, Tkatch T, Yan Z, Surmeier DJ (1998) Inwardly rectifying potassium (IRK) currents are correlated with IRK subunit expression in rat nucleus accumbens medium spiny neurons. J Neurosci 18:6650-6661.

Misgeld U, Calabresi P, Dodt HU (1986) Muscarinic modulation of calcium dependent plateau potentials in rat neostriatal neurons. Pflügers Arch 407:482-487.

Nisenbaum ES, Wilson CJ (1995) Potassium currents responsible for inward and outward rectification in rat neostriatal spiny projection neurons. J Neurosci 15:4449-4463.

Olianas MC, Adem A, Karlsson E, Onali P (1996) Rat striatal muscarinic receptors coupled to inhibition of adenylyl cyclase activity: potent block by the selective $\mathrm{m}_{4}$ ligand muscarinic toxin 3 (MT3). $\mathrm{Br} \mathrm{J}$ Pharmacol 118:283-288.

Pacheco-Cano MT, Bargas J, Hernández-López S, Tapia D, Galarraga E (1996) Inhibitory action of dopamine involves a subthreshold $\mathrm{Cs}^{+}$sensitive conductance in neostriatal neurons. Exp Brain Res 110:205-211.

Pineda JC, Bargas J, Flores-Hernández J, Galarraga E (1995) Muscarinic receptors modulate the afterhyperpolarizing potential in neostriatal neurons. Eur J Pharmacol 281:271-277.

Potter LT, Purkerson SL (1995) Pharmacology of striatal cholinergic receptors. In: Molecular and cellular mechanisms of neostriatal function (Ariano MA, Surmeier DJ, eds), pp 241-254. Austin, TX: Landes.

Purkerson SL, Potter LT (1998) Use of antimuscarinic toxins to facilitate studies of striatal m4 muscarinic receptors. J Phamacol Exp Ther 284:707-713

Reyes A, Galarraga E, Flores-Hernández J, Tapia D, Bargas J (1998)
Passive properties of neostriatal neurons during potassium conductance blockade. Exp Brain Res 120:70-84.

Riederer P, Lange KW, Youdim MBH (1993) Recent advances in pharmacological therapy of Parkinson's disease. In: Parkinson's disease: from basic research to treatment, Advances in Neurology 60 (Narabayashi H, Nagatsu T, Yanagisawa N, Mizuno Y, eds), pp 626-635. New York: Raven.

Shen KZ, North RA (1992) Muscarine increases cation conductance and decreases potassium conductance in rat locus coeruleus neurons. J Physiol (Lond) 455:471-485.

Surmeier DJ, Bargas J, Hemmings HC, Nairn AC, Greengard P (1995) Modulation of calcium currents by a D1 dopaminergic protein kinase/ phosphatase cascade in rat neostriatal neurons. Neuron 14:385-397.

Tukey JW (1977) Exploratory data analysis. Menlo Park, CA: Addison-Wesley.

Uchimura N, North RA (1990) Muscarine reduces inwardly rectifying potassium conductance in rat nucleus accumbens neurones. J Physiol (Lond) 422:369-380.

Vilchis MC, Ayala GX, Galarraga E, Bargas J (1998) Calcium channels that activate $\mathrm{Ca}^{2+}$ activated $\mathrm{K}^{+}$currents in neostriatal projection neurons. Soc Neurosci Abstr 24:1640.

Wang JQ, McGinty JF (1997) Intrastriatal injection of a muscarinic receptor agonist and anatgonist regulates striatal neuropeptide mRNA expression in normal and amphetamine-treated rats. Brain Res 748:62-70.

Weiler M (1989) Muscarinic modulation of endogenous acetylcholine release in rat neostriatal slices. J Pharmacol Exp Ther 250:617-623.

Weiner D, Levey A, Brann M (1990) Expression of muscarinic acetylcholine and dopamine receptor mRNAs in rat basal ganglia. Neurobiology 87:7050-7054.

Wilson CJ (1998) Basal ganglia. In: The synaptic organization of the brain (Shepherd GM, ed), pp 279-316. Oxford: Oxford UP.

Wilson CJ, Chang HT, Kitai ST (1990) Firing patterns and synaptic potentials of identified giant aspiny interneurons in the rat neostriatum. J Neurosci 10:508-519.

Yan Z, Surmeier DJ (1996) Muscarinic (m2/m4) receptors reduce Nand $\mathrm{P}$-type $\mathrm{Ca}^{2+}$ currents in rat neostriatal cholinergic interneurons through a fast, membrane-delimited, G-protein pathway. J Neurosci $16: 2592-2604$. 